\title{
A Proposed English Syllabus for the Marketing Staff of PT Dharma Medipro
}

\author{
Siti Tuti Alawiyah \\ Fakultas Sastra, Universitas Nasional \\ Email: tuti.alawiyah.sta@gmail.com \\ HP: 081285410366
}

\begin{abstract}
ABSTRAK
Sejak bahasa Inggris digunakan sebagai alat komunikasi dalam dunia bisnis internasional, maka perusahaanperusahaan pun mewajibkan para karyawannya menguasai bahasa Inggris, terutama untuk staf marketing. Staf marketing dianggap memiliki peranan penting untuk mengembangkan perusahaan dan bertanggung jawab untuk mencari pelanggan dan mempromosikan produk perusahaan mereka. Oleh karena itu, PT Dharma Medipro yang memiliki pelanggan asing mewajibkan marketing staffnya meningkatkan kemampuan bahasa Inggris mereka dengan memberikan kursus bahasa Inggris untuk mereka. Analisa kebutuhan perlu dilakukan sebelum merancang silabus kursus, dengan cara memberikan kuisioner dan wawancara kepada staf marketing dan manajer marketing untuk mendapkatkan hal-hal yang berkaitan dengan deskripsi pekerjaan staf marketing. Setelah itu, hasil pengumpulan data analisis kebutuhan diolah untuk membuat silabus kursus mereka. Diyakini bahwa silabus yang dibuat berdasarkan pada kebutuhan siswa akan lebih efektif dan tujuan siswa untuk belajar bahasa Inggris dapat tercapai dengan baik. Hasil riset menunjukkan bahwa partisipan perlu meningkatkan semua kecakapan bahasa Inggis mereka terutama, kecakapan berbicara, dan menyimak. Oleh sebab itu, silabus yang diajukan menggabungkan unsur tata bahasa, fungsi, dan situasi yang berhubungan dengan staf marketing PT Dharma Medipro.
\end{abstract}

Kata kunci: staf marketing, ESP, analisis kebutuhan, desain silabus

\begin{abstract}
Since English is used as a means of communication in doing bussiness internationally, companies require their employees to master English, especially their marketing staff. The marketing staff has an important role to develop a company since they are responsible for finding customers and promoting company's products. Therefore, PT Dharma Medipro whose customers are foreigners requires its marketing staff to improve their English by providing them an English course. Before designing the course, needs analysis was conducted through questionnaires that were distributed to the marketing staff and an interview with a marketing manager to obtain more insights about marketing staff's job descriptions. Some of the marketing staff were also interviewed. Afterwards, the results of the needs analysis were interpreted to design a syllabus for them. It is believed that the syllabus based on learners' needs will be more effective and learners' goal to learn English can be achieved as well. The results indicate that the participants need to improve all skills, particularly speaking and listening. Hence, the proposed syllabus combines structure, functions and situations relevant for the marketing staff of PT Dharma Medipro.
\end{abstract}

Key words: marketing staff, ESP, needs analysis, syllabus design

\section{BACKGROUND}

Since trading companies expand their business throughout the world, they require their employees to be proficient in English. According to Zhang (2007) as stated in Jiang (2011, p.58) "based on statistic, percentage of using English as language for working in international companies is more than $80 \%$ ". Esteban \& Perez Canado (2004, p. 137) as stated in Jiang $(20011$, p.58) also added "...English has become the primary language for doing international business". So it can be said, the key to be successful in doing business internationally is to master English. Realizing such situation, the companies will surely hire people who are capable in English or at least they support their existing employees to improve their English skills by providing them with an English course. 
One of the companies that deals with business and demand for language English communication competencies is PT Dharma Medipro which is engaged in healthcare industry. The company is a local company manufacturing healthcare equipment such as hospital beds, wheelchair, stretchers, examination table, operating Table, gynaecolog chair, medical Trolley (medicine trolley, Instrument trolley, Emergency trolley) and many others. As a manufacturing company that sells their products not only in domestic area but also to overseas, the owner/ the stake holders obligate the employees to have capability in English, especially, their sales marketing staff. A Marketing staff is a person that sells or promotes a product or a service of the company where he or she works. In general, marketing staff are responsible to sell and advertise the products, increase sales by understanding what customers want or need. Because PT. Dharma Medipro has overseas customers as well, the marketing staff are expected to be able to communicate with exisiting foreign customers or prospective customers to explain their product knowledge, make a deal with a customer, do correspondence (write and reply to an email), make a conversation via phone or teleconference by skype, and in many opportunities the marketing staff are assigned to visit another international healthcare companies abroad to present their products, or sometimes they accept customers who would like to have cooperation with their company.

This study tried to answer two research questions, namely:

1. What are the needs of Marketing staff in learning English?

2. What kind of syllabus design is appropriate to improve the communication skills and the language knowledge of marketing staff?

The purpose of this study is to seek the needs of the marketing staff in PT. Dharma Medipro to improve their English knowledge to serve customers better. Hence, the main objective of this study is to provide a proper syllabus for the marketing staff who wants to improve their English proficiency. In addition, the objective of this study is to search for the learning and target situation of the learners in order to make them perform better in the target situation.

According to its marketing manager this course aimed at improving the English proficiency of the company's marketing staff, as well as providing better communication for their customers since their duties are promoting company's products by giving presentation, sending email, or making teleconference. In addition, dealing with customer is also important, so it is necessary for them to identify the language functions in order to succeed with their professional work. The manager also added information that healthcare equipment are mostly derived from English, in fact the staff often have problems in pronouncing the names, particularly when they meet foreign customers.

Teaching for particular occupation such as marketing staff is certainly different from teaching for non professional. In this case English for Occupational Purposes (EOP) as a branch of English for Specific Purposes is more appropriate to apply. To create a fruitful syllabus and in order to get best result, teacher or course developer should conduct needs analysis. It is necessary to show the marketing staff's recent situation, target situation, and learning situation. Since the syllabus is based on learners' needs, it is likely to be motivating for learners, who see the obvious relevance of what they are studying (Basturkmen, 2006). In general, a syllabus can be defined as a framework of a course which comprises information and the objectives in every meeting are described more detailed and specifically.

According to Richard (2001), a syllabus reflects, what a teacher and learners are willing to accomplish in the end of the course and how the significance of its roles depends on the teacher's perspective on what teaching and learning should be. It is obvious that a syllabus should be associated with the present language teaching and learning situation. According to Krahnke (1987), there are six types of syllabus in language teaching. These different types of 
syllabuses rarely stay independent because actually they are not entirely distinct from one another. The syllabuses are structural (formal) syllabus, notional/functional syllabus, situational syllabus, skill-based syllabus, task based syllabus, and content based syllabus. Yalden (1991, p.93) proposed another type of syllabus, namely proportional syllabus. This syllabus is a combination of two or more syllaby. It means, the teacher or course designer is allowed to produce a proportional syllabus by combining one syllabus with another syllabus. Not only that, the teacher may decrease the weaknesses of one syllabus by using strong points found in another syllabus. The proportional syllabus, according to Yalden (1987), basically attempts to develop an "overall competence". In this study, the writer is going to choose a proportional syllabus.

In carrying out the ESP class, the materials and the methodology of teaching have been adjusted to their competence. Hence, ESP should be based on the principle of effective and efficient learning (Dudley Evan \& St. John, 1998).

Dudley-Evans \& St. John's (1998:4-5) argues that ESP should focus on profession or disciplines because it is different from general English. They specify two characteristics in ESP namely, absolute characteristic and variable characteristic as follows:

1. Absolute characteristics:

2. ESP is designed to meet specific needs of the learner;

3. ESP makes use of the underlying methodology and activities of the disciplines it serves;

4. ESP is centered on the language grammar, lexis, register, skills, discourse and genres appropriate to these activities.

2. Variable characteristics:

a. ESP may be related to or designed for specific disciplines;

b. ESP may use, in specific teaching situations, a different methodology than that of general English.

c. ESP is likely to be designed for adult learners, either at a tertiary level institution or in a professional work situation. It could, however, be used for learners at secondary school level;

d. ESP is generally designed for intermediate or advanced students. Most ESP courses assume basic knowledge of the language system, but it can be used with beginners.

The absolute and variable characteristics above distinguish ESP's features and General English's.

\section{CONDUCTING THE NEEDS ANALYSIS}

Dudley-Evans \& St. John (1998), Graves (2000), Hutchinson \& Waters (1987) and Jordan (1997) stated that the needs analysis is important to measure the learners' needs in learning English, learning preferences, current skills and proficiencies, and learning situations. If a course designer is able to interpret all mentioned above it is possible that the product of its syllabus must be good and the course will be run successfully.

In doing needs analysis, the syllabus designer should pay attention to approaches such as PSA (present situation analysis), TSA (target situation analysis), and LSA (learning situation analysis). Dudley-Evans \& St. John (1998) stated that present situation describes the learners' personal information, including their purpose in learning English, their current proficiency, and any shortcomings while target situation delineates the goals after joining the 
course. In addition, learning situation is more what the learners like to do during the course. In this study those approaches that are suggested by Dudley-Evans \& St. John (1998) are used. Particularly, this study uses methods such as questionnaires, relevant documents, and interviews to dig up learners' information or knowledge of English since those are very essential to produce beneficial syllabus. Dudley-Evans \& St. John (1998) and Graves (1996) explain that interviews, observation and document analysis are effective methods in needs analysis.

\section{METHODE RESEARCH}

\section{Distributing Questionnaires and Doing Interviews}

The mechanism to gather information is by distributing questionnaires to the people working in the field, in this case is the marketing staff. There were ten marketing staff filled the questionnaires form. According to Richards (2001), questionnaires are the most common methods for addressing a needs analysis. Questionnaires can cover a number of subjects in just a few pages. Also, points in the questionnaires make the process easy to analyze. There are two types of questionnaires. The first is questionnaires given in a structured way. Since the questionnaire is structured, the researcher provides optional responses. Next we look at questionnaires with unstructured ways, which supply open-ended questions.

Four marketing staff were interviewed in order to get more insights regarding their jobs. Another one who gives much contribution in planning a syllabus is manager of the company. He was interviewed to provide additional information because his information is useful for the course developer to develop a syllabus. Regarding the relevant documents to this study, they are obtained from product catalogs, emails from the marketing staff to customers, etc.

\section{Designing a Proportional Syllabus}

One of the factors that make the ESP course successful is because of the syllabus. That is why the course designer should be aware in arranging the steps in the syllabus itself. In this study, Yalden's approach (Yalden, 1986:25) was adopted. She proposed a proportional approach in designing a syllabus. According to her, it is possible for a course designer to combine one syllabus with another syllabus. As long as the weaknesses of one syllabus can cover the other one by its strong points. She further suggested some steps to design a syllabus

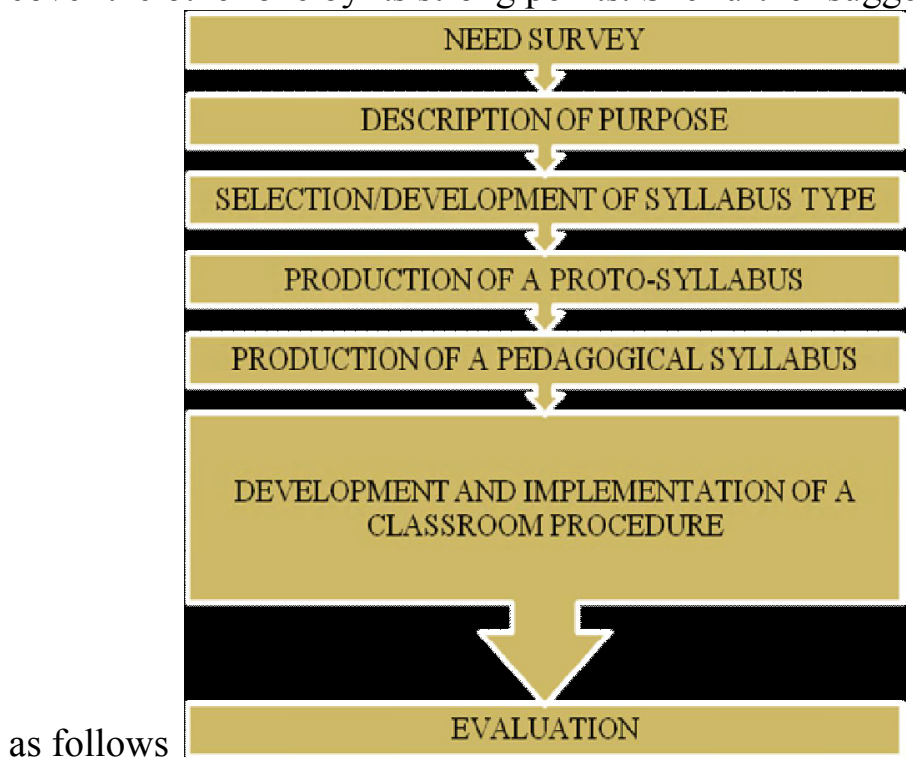


This study, covered only several steps of syllabus design. It begun from needs survey to production of a proto- syllabus for the marketing staff in PT. Dharma Medipro. Development and implementation of classroom procedures and evaluation are not included in this study.

\section{DATA ANALYSIS}

This study is quantitative and qualitative research. In the quantitative analysis marketing staffs' responses were calculated to get the illustration of the participants. The quantitative data were obtained from the information found in the questionnaires which were distributed to the marketing staff. A simple percentage analysis was used for the quantitative data. The highest percentage of responses from each question in the questionnaire shows what respondents chose mostly.

Meanwhile, the findings were analyzed descriptively and the qualitative data were collected by doing interviews to both parties, marketing staff as learners and marketing manager as the person who leads the marketing staff.

All the data from the marketing staffs and the management describes the strong points and the weaknesses about themselves towards their English competencies and also what their needs are in learning English. If both points and needs can be identified clearly, the proposed syllabus for the marketing staff can be designed as well.

\section{The Proposed Syllabus for Marketing Staff}

In this proposed syllabus for marketing staff, the writer combines structural syllabus, functional syllabus, and situational syllabus. The Structural syllabus focuses on grammatical forms. The learner is expected to master each structural pattern and recognize the pattern well since it is also important to put emphasis on communicative purpose and conceptual meaning of language the functional syllabus is also integrated. To focus on the situations that are really relevant for the participants, situational syllabus is also considered important to be integrated. It tries to predict those situations in which the learners will encounter in their work. The materials used will bring the learners to real situations in which language occurs or is used.

The reasons why the writer uses the proportional syllabus are based on the result of respondents' questionnaires and based on the findings of the interview. The results are summarized in the Table below:

\begin{tabular}{|c|c|c|c|}
\hline No & Findings & Expectations & Suggestions \\
\hline 1 & $\begin{array}{l}\text { Speaking is the most } \\
\text { important skill to learn }\end{array}$ & $\begin{array}{l}\text { a. They want to be able to } \\
\text { speak English with } \\
\text { foreign customers } \\
\text { b. They want to be able to } \\
\text { give presentations } \\
\text { about company profile } \\
\text { or products knowledge } \\
\text { well } \\
\text { c. For personal } \\
\text { development }\end{array}$ & $\begin{array}{l}\text { a. Watching a video about } \\
\text { individual or group } \\
\text { presentations, doing } \\
\text { role plays, and } \\
\text { discussion with peers } \\
\text { are useful activities to } \\
\text { improve English } \\
\text { speaking skill } \\
\text { b. Learning functions of } \\
\text { particular expressions } \\
\text { are very helpful }\end{array}$ \\
\hline 2 & The next two skills to & a. They want to be able to & a. Listening to audio- \\
\hline
\end{tabular}




\begin{tabular}{|c|c|c|c|}
\hline & $\begin{array}{l}\text { learn are listening and } \\
\text { reading }\end{array}$ & $\begin{array}{l}\text { understand the } \\
\text { conversation on the } \\
\text { phone } \\
\text { b. They want to be able to } \\
\text { comprehend the texts in } \\
\text { catalogues or brochures } \\
\text { c. They want to be able to } \\
\text { improve vocabulary } \\
\text { related to medical } \\
\text { equipment and } \\
\text { marketing area } \\
\text { d. They want to be able to } \\
\text { pronounce or spell the } \\
\text { words correctly }\end{array}$ & $\begin{array}{l}\text { taped materials are } \\
\text { helpful to understand } \\
\text { the conversation on the } \\
\text { phone } \\
\text { b. Exercises to answer } \\
\text { questions based on the } \\
\text { texts in catalogues or } \\
\text { brochures, giving } \\
\text { skimming and scanning } \\
\text { practice. } \\
\text { c. Vocabulary exercsises, } \\
\text { find difficult words } \\
\text { from online dictionary } \\
\text { and memorize them. } \\
\text { d. Practice pronounciation } \\
\text { while listening, } \\
\text { speaking, or reading } \\
\text { activities conducted. } \\
\text { For example, teacher } \\
\text { asks students to repeat } \\
\text { the words after they } \\
\text { heard from audio tape } \\
\text { or online dictionary }\end{array}$ \\
\hline 3 & $\begin{array}{l}\text { Most of the } \\
\text { respondents admitted } \\
\text { that they were weak in } \\
\text { grammar }\end{array}$ & $\begin{array}{l}\text { a. They want to be able to } \\
\text { improve grammar } \\
\text { knowledge } \\
\text { b. They want to be able to } \\
\text { speak English in } \\
\text { grammatically correct }\end{array}$ & $\begin{array}{l}\text { a. Grammar exercises } \\
\text { should be given in } \\
\text { sessions in the course }\end{array}$ \\
\hline 4 & $\begin{array}{l}\text { There were some of } \\
\text { the respondents found } \\
\text { difficulties in } \\
\text { pronounciation }\end{array}$ & $\begin{array}{l}\text { a. They want to be able to } \\
\text { pronounce or spell the } \\
\text { words correctly }\end{array}$ & $\begin{array}{l}\text { e. Practice pronounciation } \\
\text { while listening, } \\
\text { speaking, or reading } \\
\text { activities conducted. } \\
\text { For example, teacher } \\
\text { asks students to repeat } \\
\text { the words after they } \\
\text { heard from audio tape } \\
\text { or online dictionary }\end{array}$ \\
\hline 5 & $\begin{array}{l}\text { There were some of } \\
\text { the respondents found } \\
\text { difficulties in } \\
\text { understanding the } \\
\text { texts in product } \\
\text { catalogues or } \\
\text { brochures because } \\
\text { they lacked of } \\
\text { vocabulary }\end{array}$ & $\begin{array}{l}\text { a. They want to be able to } \\
\text { comprehend the texts } \\
\text { and vocabulary } \\
\text { excersises to improve } \\
\text { their vocabulary } \\
\text { b. They want to be able to } \\
\text { capture detailed } \\
\text { information from the } \\
\text { texts }\end{array}$ & $\begin{array}{l}\text { a. Reading activity such } \\
\text { as answers questions } \\
\text { based on catalogs or } \\
\text { brochure } \\
\text { b. finding difficult words } \\
\text { and finding their } \\
\text { meanings from online } \\
\text { dictionary } \\
\text { c. giving scanning and } \\
\text { skimming techniques }\end{array}$ \\
\hline
\end{tabular}




\begin{tabular}{|c|c|c|c|}
\hline & & & $\begin{array}{l}\text { and practice them. } \\
\text { d. vocabulary exersises }\end{array}$ \\
\hline 6 & $\begin{array}{l}\text { A few of the } \\
\text { respondents admitted } \\
\text { that they found } \\
\text { difficulties in writing. }\end{array}$ & $\begin{array}{l}\text { a. They want to be able to } \\
\text { write and respond } \\
\text { emails to customers } \\
\text { correctly }\end{array}$ & $\begin{array}{l}\text { a. Giving formal } \\
\text { expressions in writing } \\
\text { b. Grammar-focused } \\
\text { exercises }\end{array}$ \\
\hline
\end{tabular}

The distribution of lessons and contents of the syllabus can be seen in the next pages.

The syllabus for the marketing staff in PT Darma Medipro

Level : one

Total hours : 30

Session 1:

Schedule : twice a week

\begin{tabular}{|c|c|c|c|c|}
\hline $\begin{array}{c}\text { Time } \\
\text { allotment }\end{array}$ & Topic/content & Learning outcomes & $\begin{array}{c}\text { Language } \\
\text { components }\end{array}$ & $\begin{array}{c}\text { Class } \\
\text { activities }\end{array}$ \\
\hline 2 hours & $\begin{array}{l}\text { 1. Introducing } \\
\text { themselves } \\
\text { 2. Talking to } \\
\text { the current } \\
\text { foreign } \\
\text { customers } \\
\text { 3. Talking to } \\
\text { the } \\
\text { prospective } \\
\text { current } \\
\text { foreign } \\
\text { customers }\end{array}$ & $\begin{array}{l}\text { Structure: } \\
\text { Participants are able to: } \\
\text { - use auxiliary verbs } \\
\text { (do, does, is, am, are) } \\
\text { correctly. } \\
\text { - make yes-no } \\
\text { questions. make } \\
\text { questions by using } \\
\text { question word (What, } \\
\text { Who, Where, When, } \\
\text { How). } \\
\text { - respond to questions } \\
\text { Vocabulary: } \\
\text { Participants are able to } \\
\text { use sufficient } \\
\text { vocabulary to introduce }\end{array}$ & $\begin{array}{l}\text { Auxiliary verbs, } \\
\text { i.e. is, am, are, } \\
\text { do, and does. } \\
\text { Question } \\
\text { words,i.e.what, } \\
\text { who,where,when, } \\
\text { and how) } \\
\text { Greetings: } \\
\text { Good Morning, } \\
\text { Good Afternoon, } \\
\text { Good Evening, }\end{array}$ & $\begin{array}{l}\text { - Teacher } \\
\text { explains the } \\
\text { materials } \\
\text { they are } \\
\text { going to } \\
\text { study in the } \\
\text { meeting. } \\
\text { Teacher and } \\
\text { participants } \\
\text { negotiate } \\
\text { about the } \\
\text { regulation of } \\
\text { the clas } \\
\text { - Teacher } \\
\text { explains } \\
\text { auxiliary }\end{array}$ \\
\hline
\end{tabular}




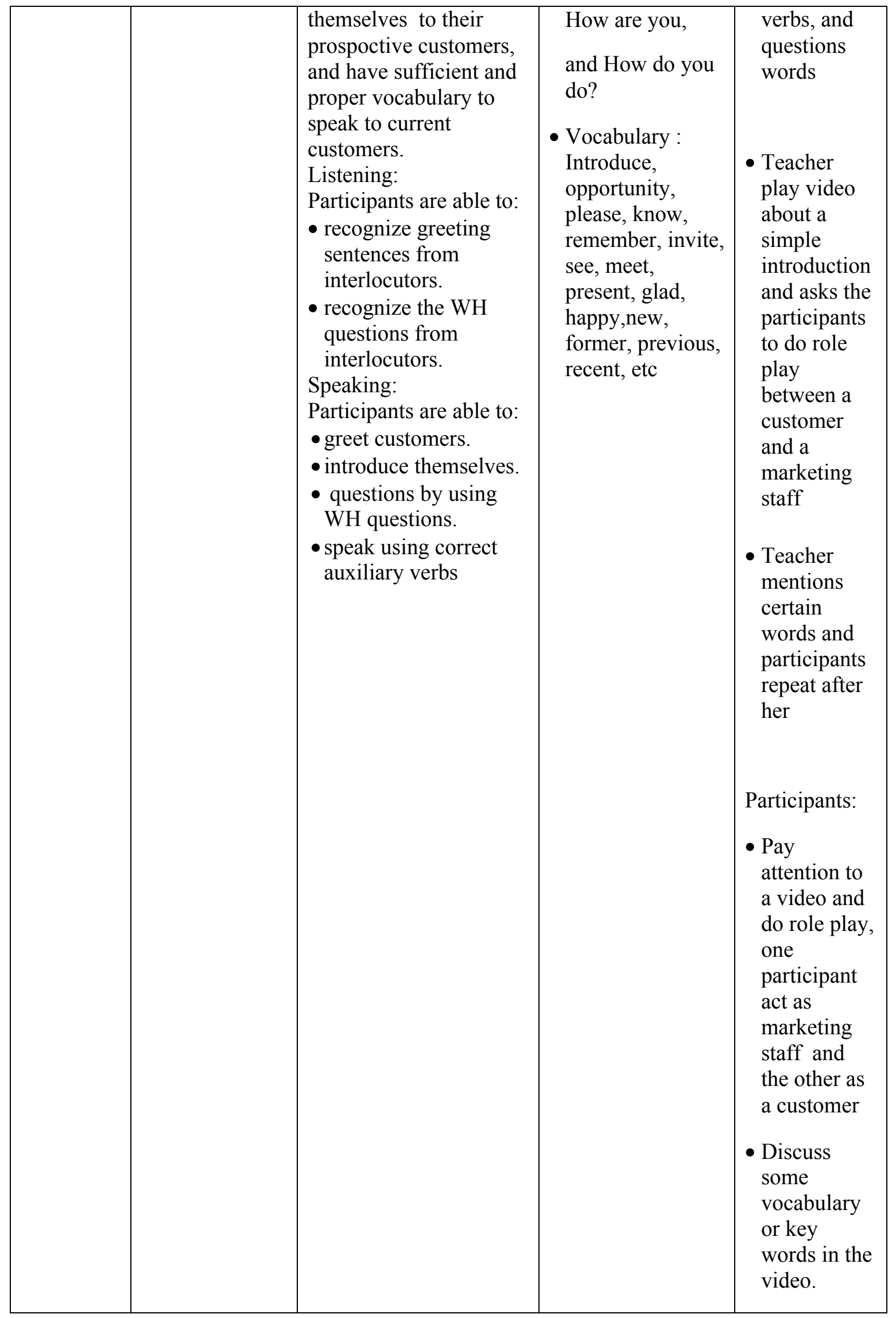




\begin{tabular}{|l|l|l|l|l|}
\hline & & & $\begin{array}{c}\bullet \text { Practice } \\
\text { making } \\
\text { questions }\end{array}$ \\
& & & & \\
\hline
\end{tabular}

Session 2:

\begin{tabular}{|c|c|c|c|c|}
\hline $\begin{array}{c}\text { Time } \\
\text { allotment }\end{array}$ & Topic/content & $\begin{array}{l}\text { Learning } \\
\text { outcomes }\end{array}$ & $\begin{array}{c}\text { Language } \\
\text { components }\end{array}$ & Class activities \\
\hline 2 hours & $\begin{array}{l}\text { Company's } \\
\text { Profile } \\
\text { Presentation } \\
\text { slides }\end{array}$ & $\begin{array}{l}\text { Structure: } \\
\text { Participants are } \\
\text { able to : } \\
\text { - A differentiate } \\
\text { Adjectives and } \\
\text { Adverbs } \\
\text { - put adjectives } \\
\text { and adverbs in } \\
\text { the correct } \\
\text { position } \\
\text { - design their } \\
\text { own } \\
\text { company's } \\
\text { profile } \\
\text { presentation } \\
\text { slides } \\
\text { - use simple } \\
\text { present \& } \\
\text { present } \\
\text { continuous } \\
\text { tenses } \\
\text { Vocabulary: } \\
\text { Participants can } \\
\text { use some } \\
\text { adjectives and } \\
\text { adverbs that are } \\
\text { often found in a } \\
\text { company's } \\
\text { profile. } \\
\text { Writing : } \\
\text { Participants are } \\
\text { able to show } \\
\text { others the } \\
\text { ond }\end{array}$ & $\begin{array}{l}\text { - Simple } \\
\text { present } \\
\text { tenses, and } \\
\text { past tense } \\
\text { - Adjective and } \\
\text { adverbs for } \\
\text { presenting a } \\
\text { company's } \\
\text { profile. }\end{array}$ & $\begin{array}{l}\text { - Teacher explains about } \\
\text { adjective, adverbs, } \\
\text { simple present tense, } \\
\text { and past tense } \\
\text { - Teacher plays aviedo } \\
\text { about presenting } \\
\text { company profile } \\
\text { - Teacher asks } \\
\text { participants to present } \\
\text { their company's profile } \\
\text { individually } \\
\text { - Teacher asks } \\
\text { participants to discuss } \\
\text { or give comments on } \\
\text { their friends' } \\
\text { presentation } \\
\text { Paticipants: } \\
\text { - Discuss their friends' } \\
\text { performences. } \\
\text { vocabulary or key } \\
\text { words in their } \\
\text { presentation. } \\
\text { carefully } \\
\text { - Decide some } \\
\text { characteristics of their } \\
\text { company which they } \\
\text { will put on their slides. } \\
\text { present company's } \\
\text { - }\end{array}$ \\
\hline
\end{tabular}




\begin{tabular}{|c|c|c|}
\hline & & $\begin{array}{l}\text { highlights of } \\
\text { their company in } \\
\text { their } \\
\text { presentation } \\
\text { slides } \\
\text { Speaking : } \\
\text { Participants } \\
\text { give a } \\
\text { presentation } \\
\text { about their } \\
\text { company's } \\
\text { profile }\end{array}$ \\
\hline
\end{tabular}

\section{Session 3:}

\begin{tabular}{|c|c|c|c|c|}
\hline $\begin{array}{c}\text { Time } \\
\text { allotment }\end{array}$ & Topic/content & $\begin{array}{l}\text { Learning } \\
\text { outcomes }\end{array}$ & $\begin{array}{l}\text { Language } \\
\text { components }\end{array}$ & Class activities \\
\hline 2 hours & $\begin{array}{l}\text { 4. Presenting } \\
\text { and } \\
\text { describing } \\
\text { the } \\
\text { company's } \\
\text { products } \\
\text { (part I) }\end{array}$ & $\begin{array}{l}\text { Structure: } \\
\text { Participants are } \\
\text { able to: } \\
\text { - identify the } \\
\text { correct forms } \\
\text { of verbs in } \\
\text { perfect tense } \\
\text { - noun phrase } \\
\text { form } \\
\text { - use countable } \\
\text { and } \\
\text { uncountable } \\
\text { nouns } \\
\text { Vocabulary: } \\
\text { Participants are } \\
\text { able to use } \\
\text { adjectives to } \\
\text { describe the } \\
\text { specification of } \\
\text { items. i.e: big, } \\
\text { small, low, high, } \\
\text { strong, good, the }\end{array}$ & $\begin{array}{l}\text { - } \text { Present } \\
\text { continous } \\
\text { tense and } \\
\text { perfect tense. } \\
\text { - Noun phrase } \\
\text { - Countable \& } \\
\text { uncountable } \\
\text { nouns }\end{array}$ & $\begin{array}{l}\text { - Teacher explains } \\
\text { present perfect tense, } \\
\text { noun phrases, and } \\
\text { nouns. } \\
\text { - Teacher gives some } \\
\text { texts about certain } \\
\text { products and asks } \\
\text { participants to read } \\
\text { carefully and answer } \\
\text { the questions } \\
\text { - plays a video in which } \\
\text { someone is describing } \\
\text { products of a company. } \\
\text { - Teacher asks } \\
\text { participants to do role } \\
\text { playa and describe their } \\
\text { own company's } \\
\text { products } \\
\text { Participants: } \\
\text { - Do role play, a } \\
\text { marketing staff } \\
\text { presents his or her }\end{array}$ \\
\hline
\end{tabular}




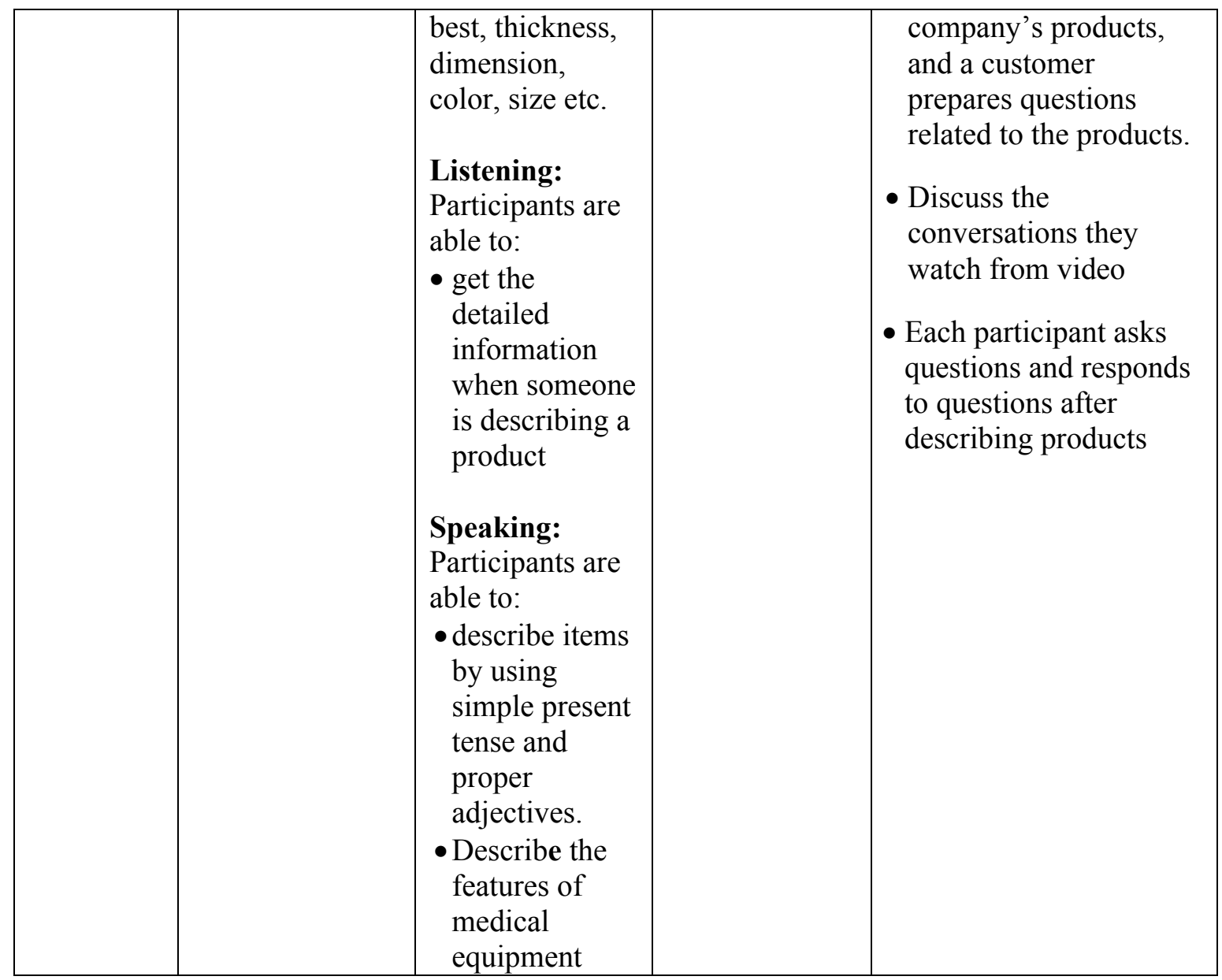

Session 4:

\begin{tabular}{|c|c|c|c|c|}
\hline $\begin{array}{c}\text { Time } \\
\text { allotment }\end{array}$ & Topic/content & $\begin{array}{l}\text { Learning } \\
\text { outcomes }\end{array}$ & $\begin{array}{c}\text { Language } \\
\text { components }\end{array}$ & Class activities \\
\hline 2 hours & $\begin{array}{l}\text { 5. Presenting } \\
\text { and } \\
\text { describing } \\
\text { company's } \\
\text { products } \\
\text { (part II) }\end{array}$ & $\begin{array}{l}\text { Structure: } \\
\text { The participants } \\
\text { are able to: } \\
\text { - Use passive } \\
\text { active voices } \\
\text { Vocabulary: } \\
\text { Participants are } \\
\text { able to: } \\
\text { - use noun and } \\
\text { noun phrases } \\
\text { when } \\
\text { describing } \\
\text { company's } \\
\text { products. } \\
\text { - Learn more }\end{array}$ & $\begin{array}{l}\text { - passive } \\
\text { active voices } \\
\text { - noun phrases } \\
\text { and } \\
\text { adjectives }\end{array}$ & $\begin{array}{l}\text { - Teacher explains } \\
\text { passive active voices } \\
\text { - Teacher gives the texts } \\
\text { related to the healthcare } \\
\text { devices and asks } \\
\text { participants to answer } \\
\text { the questions correctly. } \\
\text { - Teacher gives grammar } \\
\text { and vocabulary } \\
\text { excercises such as } \\
\text { choosing the right } \\
\text { forms of verbs, correct } \\
\text { adjectives. }\end{array}$ \\
\hline
\end{tabular}




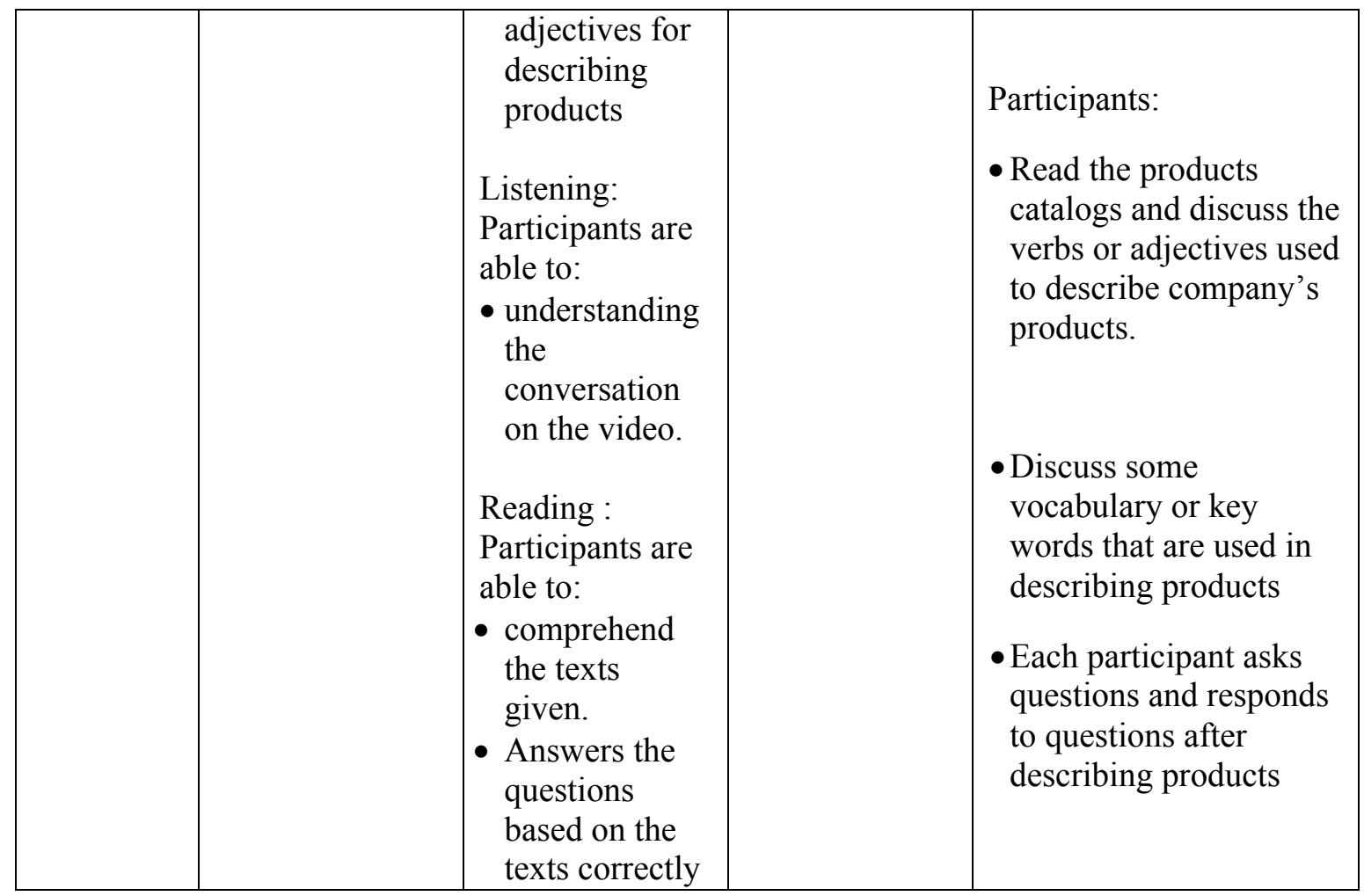

Session 5:

\begin{tabular}{|c|c|c|c|c|}
\hline $\begin{array}{c}\text { Time } \\
\text { allotment }\end{array}$ & Topic/content & $\begin{array}{l}\text { Learning } \\
\text { outcomes }\end{array}$ & $\begin{array}{c}\text { Language } \\
\text { components }\end{array}$ & Class activities \\
\hline 2 hours & $\begin{array}{l}\text { Comparing one } \\
\text { product to } \\
\text { another product }\end{array}$ & $\begin{array}{l}\text { Structure: } \\
\text { Participants are } \\
\text { able to: } \\
\text { - understand the } \\
\text { comparative } \\
\text { degree } \\
\text { - distinguish } \\
\text { adjective, } \\
\text { comparative, } \\
\text { and } \\
\text { superlative } \\
\text { forms } \\
\text { Vocabulary: } \\
\text { Participants are } \\
\text { able to use } \\
\text { some adjectives, } \\
\text { noun and } \\
\text { adverbs that are } \\
\text { often found in a } \\
\text { product catalog }\end{array}$ & $\begin{array}{l}\text { - The forms of } \\
\text { adjective, } \\
\text { comparative, } \\
\text { and } \\
\text { superlative. } \\
\text { Examples: } \\
\text { Adjective } \\
\text { - profitable } \\
\text { - high } \\
\text { - low } \\
\text { - new } \\
\text { - old } \\
\text { - expensive } \\
\text {-good } \\
\text { Comparative: } \\
\text { - higher } \\
\text { - lower } \\
\text { - better }\end{array}$ & $\begin{array}{l}\text { - Teacher shows } \\
\text { different things and } \\
\text { explains the } \\
\text { comparative, } \\
\text { superlative by using } \\
\text { pictures } \\
\text { - Teacher asks } \\
\text { participants to do a } \\
\text { group discussion and } \\
\text { asks them to discuss } \\
\text { the } \\
\text { strengths and weakness } \\
\text { of their products. } \\
\text { - Teacher gives } \\
\text { vocabulary-excercises } \\
\text { Participants: } \\
\text { - will see medical } \\
\text { pictures shown on } \\
\text { slides and then they }\end{array}$ \\
\hline
\end{tabular}




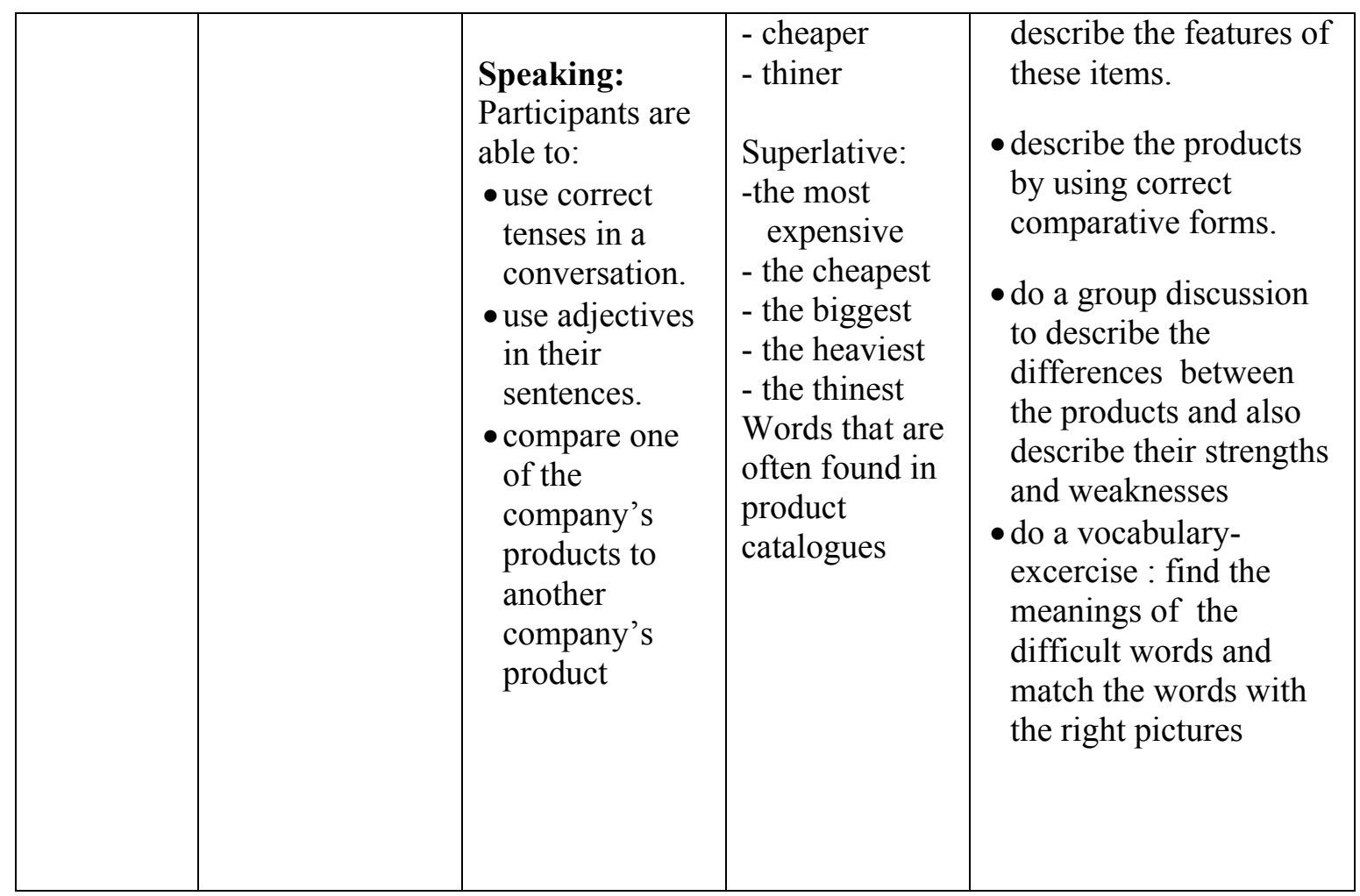

Session 6:

\begin{tabular}{|c|c|c|c|c|}
\hline $\begin{array}{c}\text { Time } \\
\text { allotment }\end{array}$ & Topic/content & $\begin{array}{l}\text { Learning } \\
\text { outcomes }\end{array}$ & $\begin{array}{c}\text { Language } \\
\text { components }\end{array}$ & Class activities \\
\hline 2 hours & $\begin{array}{l}\text { Dealing with } \\
\text { number of } \\
\text { products or the } \\
\text { prices of } \\
\text { products }\end{array}$ & $\begin{array}{l}\text { Structure: } \\
\text { Participants are } \\
\text { able to: } \\
\text { - identify } \\
\text { ordinal and } \\
\text { cardinal } \\
\text { numbers } \\
\text { - recognize and } \\
\text { comprehend } \\
\text { the amount of } \\
\text { money } \\
\text { Vocabulary: } \\
\text { Participants are } \\
\text { able to use } \\
\text { vocabulary } \\
\text { related to order } \\
\text { quantity, and } \\
\text { products' prices } \\
\text { to customers. }\end{array}$ & $\begin{array}{l}\text { - Cardinal and } \\
\text { ordinal } \\
\text { numbers } \\
\text { Examples: } \\
\text { - There are } \\
\text { seven-hundred } \\
\text { of wheelchairs } \\
\text { ordered by the } \\
\text { United } \\
\text { Nations. }\end{array}$ & $\begin{array}{l}\text { - Teacher explains about } \\
\text { cardinal and ordinal } \\
\text { numbers } \\
\text { - Teacher plays a } \\
\text { cassette about numbers } \\
\text { and asks participants to } \\
\text { listen carefully, and } \\
\text { then asks them to } \\
\text { practice to pronounce } \\
\text { the words } \\
\text { - Teacher shows the } \\
\text { pictures and the } \\
\text { pricelist, then ask } \\
\text { participants to } \\
\text { pronounce the pictures } \\
\text { and the pricelist } \\
\text { - Teacher asks } \\
\text { participants to do a role } \\
\text { play, act as a marketing } \\
\text { staff who explains the } \\
\text { products' price to a } \\
\text { customer and a }\end{array}$ \\
\hline
\end{tabular}




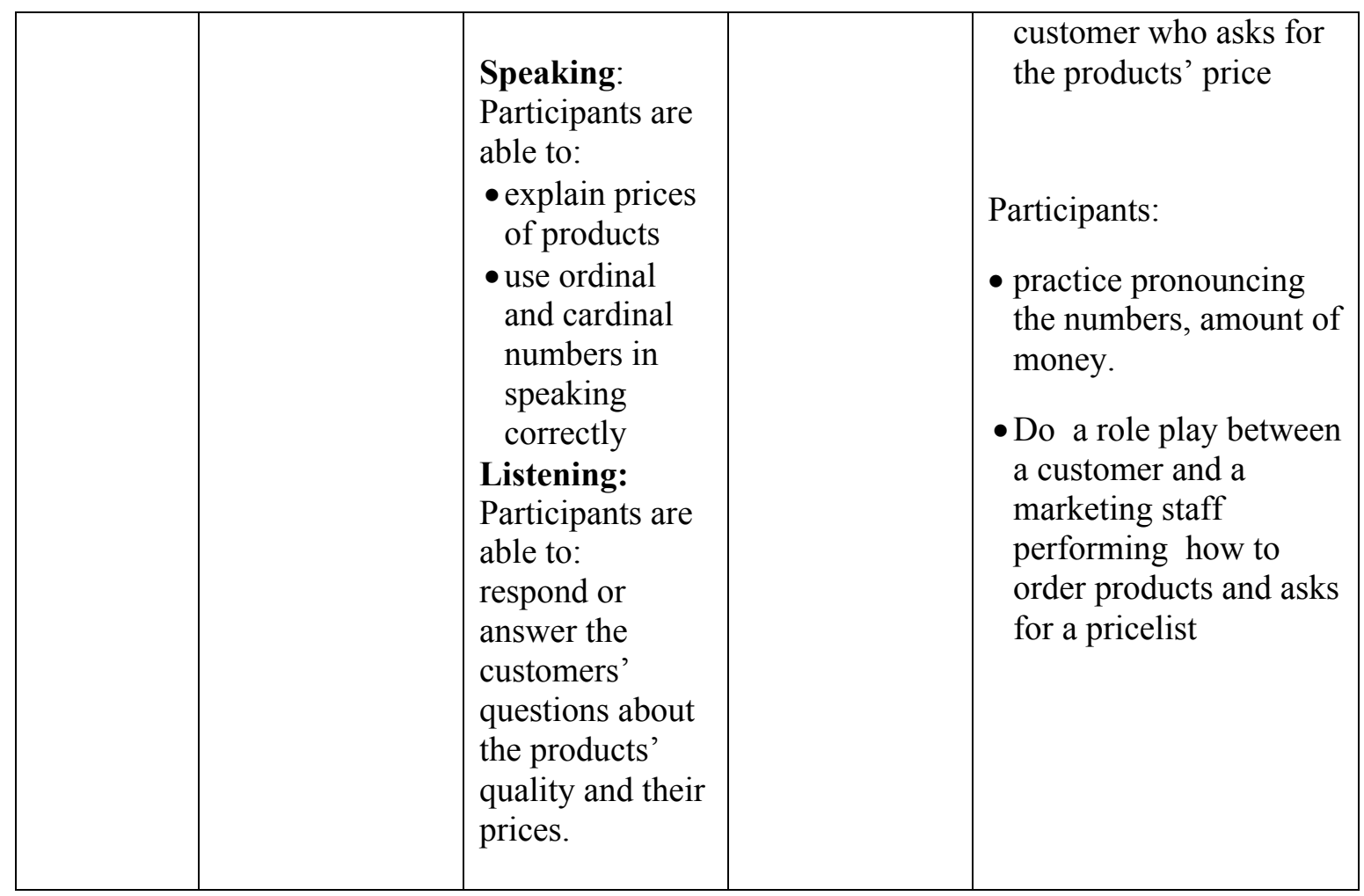

\section{Session 7:}

\begin{tabular}{|c|c|c|c|c|}
\hline $\begin{array}{c}\text { Time } \\
\text { allotment }\end{array}$ & Topic/content & Learning outcomes & $\begin{array}{l}\text { Language } \\
\text { components }\end{array}$ & Class activities \\
\hline 2 hours & $\begin{array}{l}\text { 1. Telephoning } \\
\text { 2. Telemarketi } \\
\text { ng }\end{array}$ & $\begin{array}{l}\text { Structure: } \\
\text { Participants are able to: } \\
\text { - take notes } \\
\text { - take and respond to } \\
\text { telephone calls } \\
\text { - greet on the phone } \\
\text { Vocabulary: } \\
\text { Participants are able to: } \\
\text { - use proper vocabulary } \\
\text { when talking to } \\
\text { customers on the } \\
\text { phone } \\
\text { Speaking: } \\
\text { Participants are able to: } \\
\text { - deliver their intention } \\
\text { to the customers via } \\
\text { phone and answer the } \\
\text { questions clearly. } \\
\text { - spell numbers or }\end{array}$ & $\begin{array}{l}\text { - Confirmation/ } \\
\text { tag questions } \\
\text { words (aren't, } \\
\text { isn't) } \\
\text { - introducing } \\
\text { modals such: } \\
\text {-can/ could } \\
\text {-should } \\
\text {-may/ might } \\
\text {-must } \\
\text {-shall/ shall } \\
\text { - vocabulary for } \\
\text { telephone } \\
\text { conversations }\end{array}$ & $\begin{array}{l}\text { - Teacher } \\
\text { explains the } \\
\text { confirmation } \\
\text { form/tag } \\
\text { questions } \\
\text { - Teacher } \\
\text { introduces } \\
\text { modals } \\
\text { - Teacher plays } \\
\text { a cassette } \\
\text { about } \\
\text { conversation } \\
\text { on the phone } \\
\text { and asks } \\
\text { participant to } \\
\text { explain what } \\
\text { the } \\
\text { conversation } \\
\text { is about } \\
\text { - Teacher asks } \\
\text { participants to } \\
\text { do a role play, }\end{array}$ \\
\hline
\end{tabular}




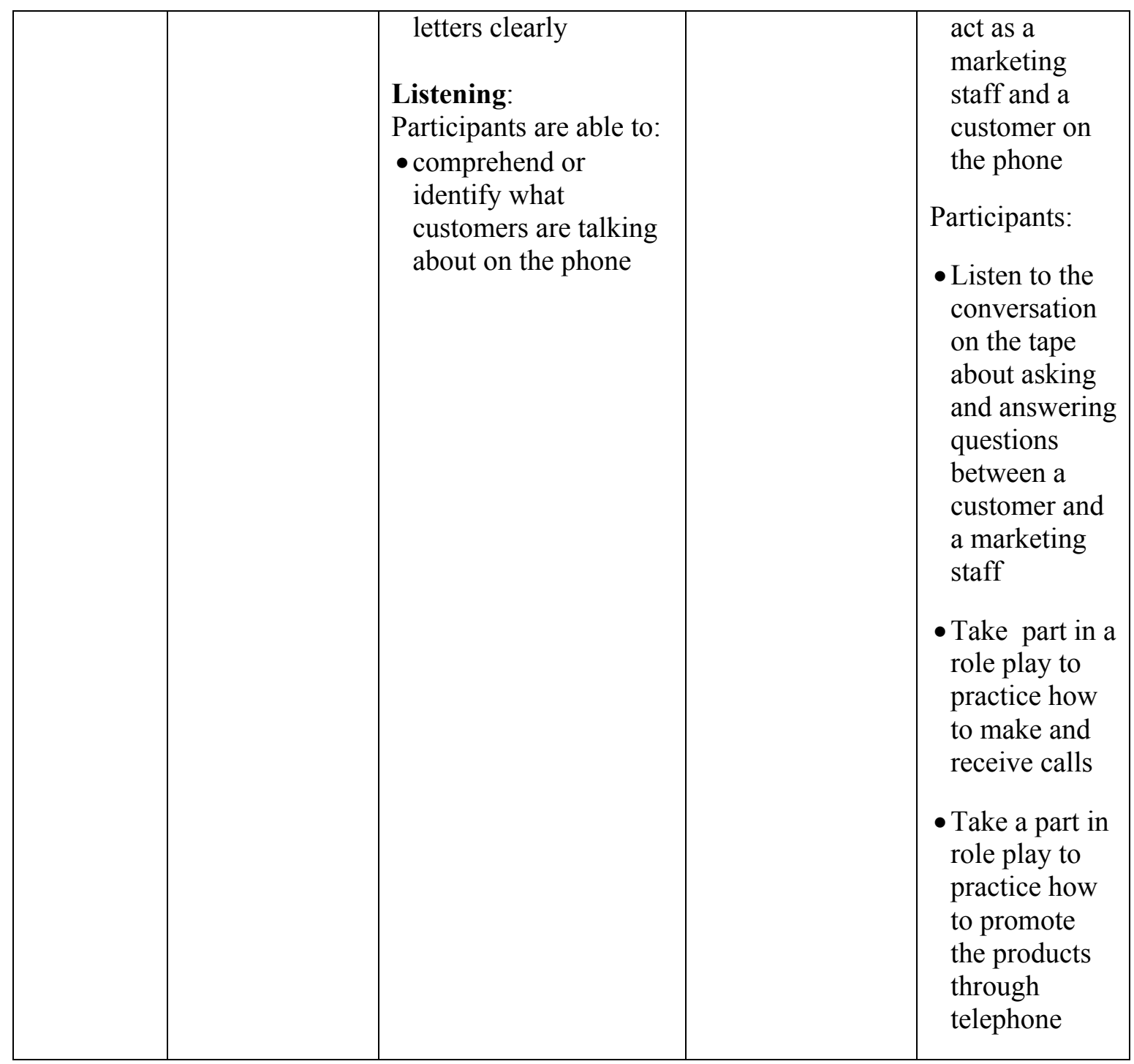

Session 8:

\begin{tabular}{|c|c|c|c|c|}
\hline $\begin{array}{c}\text { Time } \\
\text { allotment }\end{array}$ & Topic/content & $\begin{array}{l}\text { Learning } \\
\text { outcomes }\end{array}$ & $\begin{array}{c}\text { Language } \\
\text { components }\end{array}$ & Class activities \\
\hline 2 hours & $\begin{array}{l}\text { Answering } \\
\text { customers' } \\
\text { inquiries } \\
\text { (including } \\
\text { giving discount, } \\
\text { guarantee } \\
\text { procedures, } \\
\text { product quality, } \\
\text { etc) }\end{array}$ & $\begin{array}{l}\text { Structure: } \\
\text { Participants are } \\
\text { able to: } \\
\text { - identify and } \\
\text { use } \\
\text { conditional } \\
\text { sentences } \\
\text { type I and type } \\
2 \\
\text { - use modals } \\
\text { forms }\end{array}$ & $\begin{array}{l}\text { - Forms of } \\
\text { conditional } \\
\text { sentences } \\
\text { type I \& type } \\
\text { II } \\
\text { - Forms of } \\
\text { modals } \\
\text { - Vocabulary } \\
\text { related to } \\
\text { purchasing }\end{array}$ & $\begin{array}{l}\text { - Teacher explains the } \\
\text { forms of conditional } \\
\text { sentences type I \& type } \\
\text { II } \\
\text { - Teacher explains forms } \\
\text { of modals } \\
\text { - Teacher gives grammar } \\
\text { and vocabulary } \\
\text { excercises. The } \\
\text { grammar excercises } \\
\text { focuses on conditional } \\
\text { sentences and modals }\end{array}$ \\
\hline
\end{tabular}




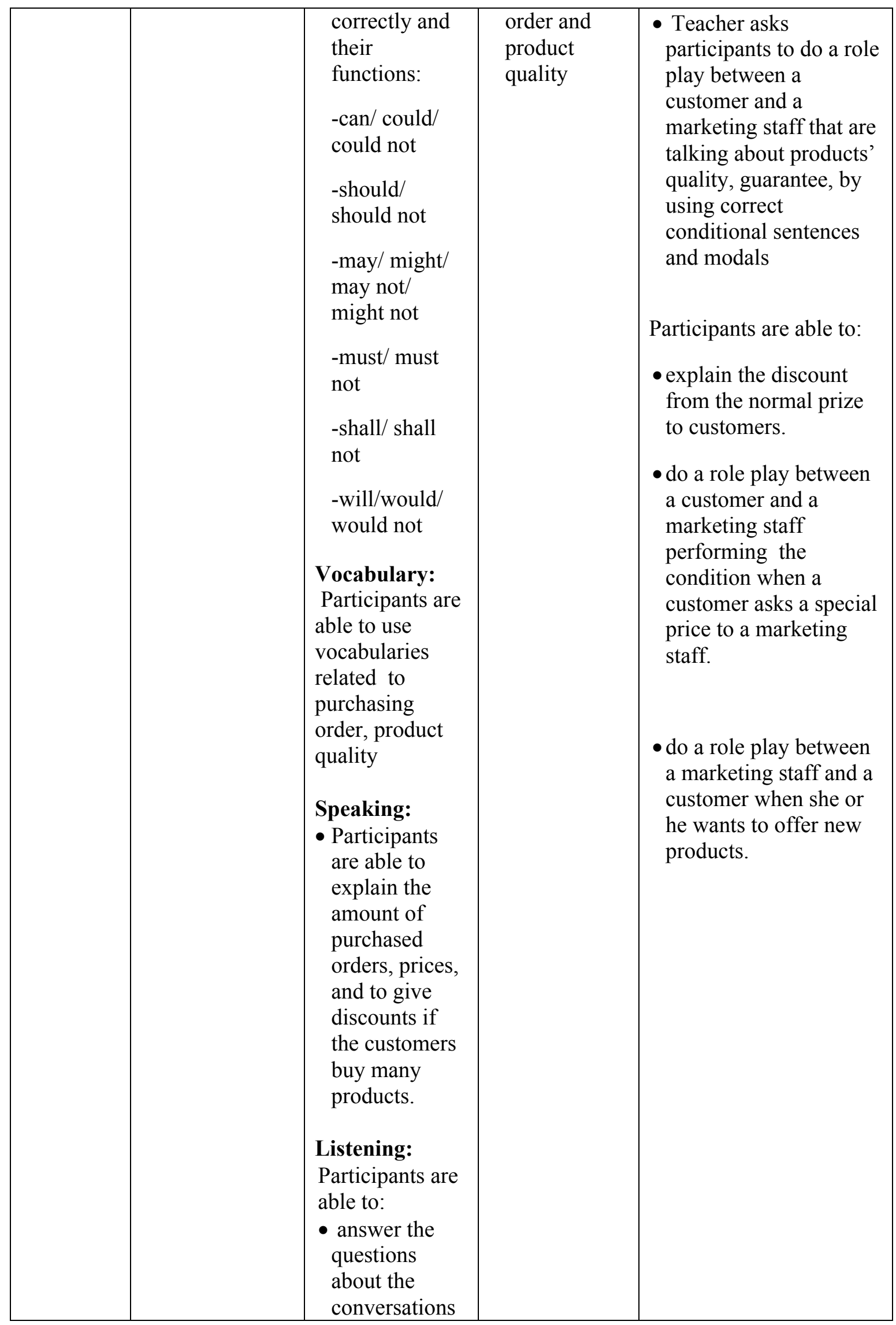




\begin{tabular}{|l|l|l|l|l|}
\hline & $\begin{array}{l}\text { they have } \\
\text { listened to }\end{array}$ & & \\
& & & & \\
& & & & \\
\hline
\end{tabular}

Session 9:

\begin{tabular}{|c|c|c|c|c|}
\hline $\begin{array}{c}\text { Time } \\
\text { allotment }\end{array}$ & Topic/content & $\begin{array}{c}\text { Learning } \\
\text { outcomes }\end{array}$ & $\begin{array}{c}\text { Language } \\
\text { components }\end{array}$ & Class activities \\
\hline 2 hours & $\begin{array}{l}\text { Handling } \\
\text { customers' } \\
\text { complaints }\end{array}$ & $\begin{array}{l}\text { Structure: } \\
\text { Participants are } \\
\text { able to: } \\
\text { - } \quad \text { express } \\
\text { regrets } \\
\text { - } \quad \text { express } \\
\text { apologies } \\
\text { - } \quad \text { express } \\
\text { promises } \\
\text { - express } \\
\text { excuses } \\
\text { Vocabulary: } \\
\text { Participants are } \\
\text { able to: } \\
\text { - use proper } \\
\text { vocabulary to } \\
\text { respond to } \\
\text { customers who } \\
\text { are } \\
\text { unsatiesfied } \\
\text { with the } \\
\text { products or }\end{array}$ & $\begin{array}{l}\text { - expression of } \\
\text { regrets } \\
\text { - expression of } \\
\text { apologies } \\
\text { - expression of } \\
\text { promises } \\
\text { - expression of } \\
\text { excuses }\end{array}$ & $\begin{array}{l}\text { - Teacher gives } \\
\text { examples of } \\
\text { expressions used to } \\
\text { express regrets, } \\
\text { promises, apologies } \\
\text { - Teacher asks } \\
\text { participants to do a role } \\
\text { play, in which one of } \\
\text { them express a } \\
\text { customer's complaint } \\
\text { and the other uses } \\
\text { correct expressions of } \\
\text { apologies, regrets, } \\
\text { promises, and excuses } \\
\text { - Teacher asks } \\
\text { participant to practice } \\
\text { how to handle } \\
\text { customers' complaints } \\
\text { on the phone }\end{array}$ \\
\hline
\end{tabular}




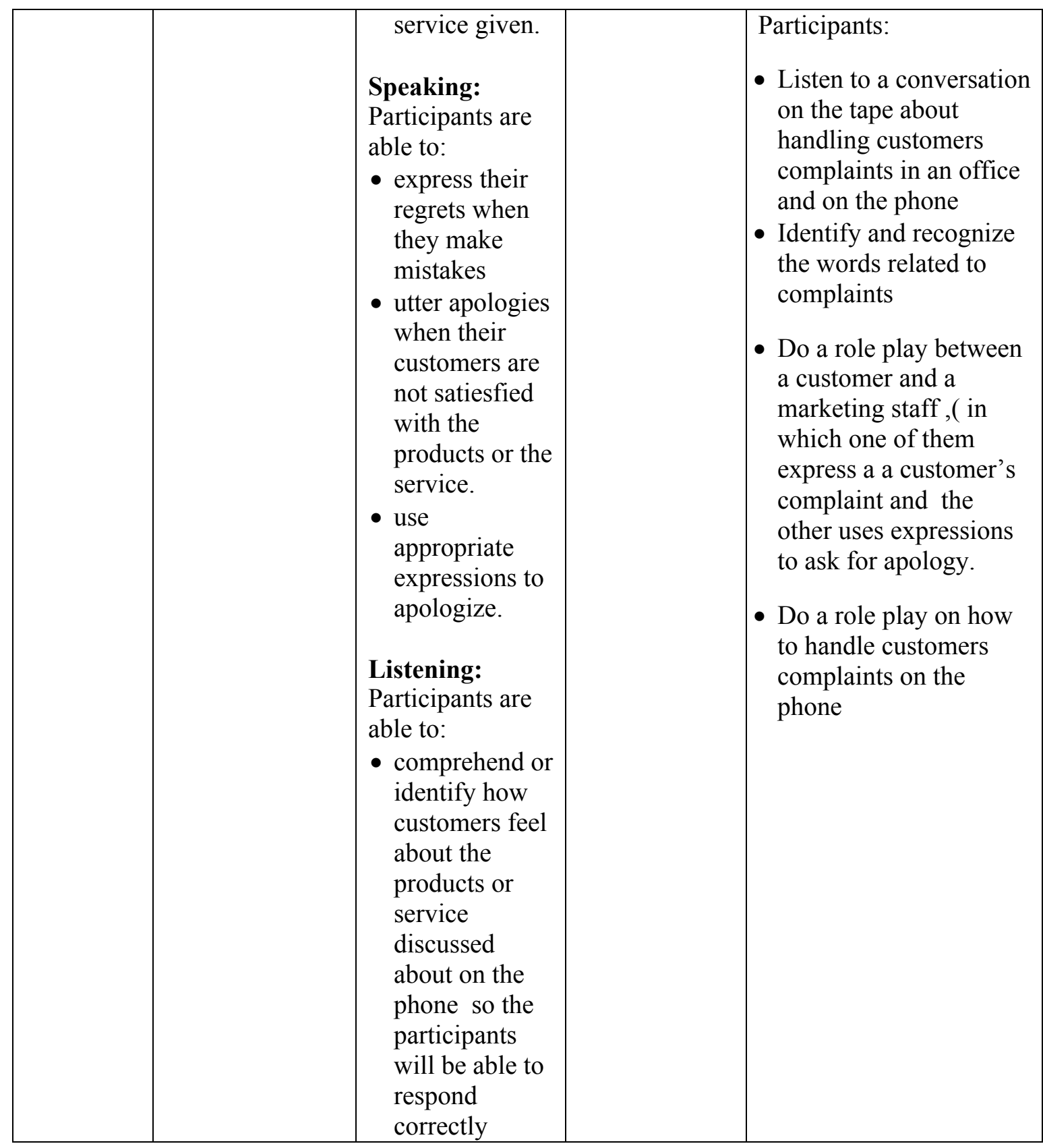

Session 10:

\begin{tabular}{|c|c|c|c|c|}
\hline $\begin{array}{c}\text { Time } \\
\text { allotment }\end{array}$ & Topic/content & $\begin{array}{c}\text { Learning } \\
\text { outcomes }\end{array}$ & $\begin{array}{c}\text { Language } \\
\text { components }\end{array}$ & Class activities \\
\hline
\end{tabular}




\begin{tabular}{|c|c|c|c|c|}
\hline 2 hours & $\begin{array}{l}\text { Offering help or } \\
\text { Giving solutions } \\
\text { to customers }\end{array}$ & $\begin{array}{l}\text { Structure: } \\
\text { Participants are } \\
\text { able to: } \\
\text { - use modals or } \\
\text { preferences } \\
\text { correctly when } \\
\text { offering help or } \\
\text { giving } \\
\text { solutions. } \\
\text { Listening: } \\
\text { Participants are } \\
\text { able to: } \\
\text { - comprehend or } \\
\text { identify what } \\
\text { problems } \\
\text { customers have } \\
\text { Speaking : } \\
\text { Participants are } \\
\text { able to: } \\
\text { - give solutions } \\
\text { to customers } \\
\text { correctly } \\
\text { use modals or } \\
\text { preferences in } \\
\text { a sentence } \\
\text { correctly }\end{array}$ & $\begin{array}{l}\text { - Modals } \\
\text { - Might } \\
\text { - Can/ could } \\
\text { - Shall/ } \\
\text { should/must } \\
\text { Examples: } \\
\text { - May I help } \\
\text { you? } \\
\text { - Can I help } \\
\text { you? } \\
\text { - Would you } \\
\text { like our } \\
\text { driver to } \\
\text { pick up the } \\
\text { devices? } \\
\text { - Could you } \\
\text { wait a } \\
\text { moment } \\
\text { until I get } \\
\text { permission } \\
\text { from my } \\
\text { boss? } \\
\text { - Would you } \\
\text { like to ...? } \\
\text { - Do you } \\
\text { mind if....? } \\
\text { - Preferences } \\
\text { - Prefer + } \\
\text { noun + to } \\
\text { +noun } \\
\text { Prefer + } \\
\text { V1ing+ to } \\
\text { V1ing }\end{array}$ & $\begin{array}{l}\text { - Teacher reviews the } \\
\text { use of modals usage, } \\
\text { and explains } \\
\text { preferences and gives } \\
\text { examples. } \\
\text { - Teacher asks } \\
\text { participants to do a role } \\
\text { play how to offer helps } \\
\text { and give solutions to } \\
\text { customers } \\
\text { - Teachers asks } \\
\text { participants to write } \\
\text { participants' } \\
\text { experiences when they } \\
\text { offered helps to a } \\
\text { customer or gave } \\
\text { solutions to a customer. } \\
\text { Then they are asked to } \\
\text { tell the story to the } \\
\text { class } \\
\text { Participants are able to: } \\
\text { do a role play between } \\
\text { a customer and a } \\
\text { marketing staff, } \\
\text { performing how to } \\
\text { offer some helps to } \\
\text { customer and give } \\
\text { solutions to customer } \\
\text { write their own } \\
\text { experiences when they } \\
\text { offered helps to a } \\
\text { customer or gave } \\
\text { solutions to a customer. }\end{array}$ \\
\hline
\end{tabular}

Session 11:

\begin{tabular}{|c|c|c|c|c|}
\hline $\begin{array}{c}\text { Time } \\
\text { allotment }\end{array}$ & Topic/content & $\begin{array}{c}\text { Learning } \\
\text { outcomes }\end{array}$ & $\begin{array}{c}\text { Language } \\
\text { components }\end{array}$ & Class activities \\
\hline
\end{tabular}




\begin{tabular}{|c|c|c|c|c|}
\hline 2 hours & $\begin{array}{l}\text { E-mails: } \\
\text { - Reading } \\
\text { emails From } \\
\text { other } \\
\text { customers or } \\
\text { companies } \\
\text { - Writing emails } \\
\text { to customers } \\
\text { or other } \\
\text { companies }\end{array}$ & $\begin{array}{l}\text { Vocabulary: } \\
\text { Participants are } \\
\text { able to } \\
\text { use proper } \\
\text { vocabulary to } \\
\text { greet and } \\
\text { express thank } \\
\text { you to others } \\
\text { through email or } \\
\text { letter } \\
\text { Reading: } \\
\text { Participants are } \\
\text { able to } \\
\text { comprehend } \\
\text { detailed } \\
\text { information on } \\
\text { email. } \\
\text { Writing: } \\
\text { Participants are } \\
\text { able to write } \\
\text { emails to } \\
\text { customers and } \\
\text { respond to their } \\
\text { emails }\end{array}$ & $\begin{array}{l}\text { - Formal } \\
\text { expressions in } \\
\text { writing an } \\
\text { email } \\
\text { - Greeting, } \\
\text { opening, } \\
\text { closing, } \\
\text { salutation in } \\
\text { an email }\end{array}$ & $\begin{array}{l}\text { - Teacher explains how } \\
\text { to write email. } \\
\text { - Teachers shows } \\
\text { examples of formal } \\
\text { emails between a } \\
\text { marketing staff to a } \\
\text { customer } \\
\text { Participants: } \\
\text { - read e-mails from } \\
\text { customers or } \\
\text { companies } \\
\text { - try to understand the } \\
\text { intentions of the e- } \\
\text { mails } \\
\text { - find the meanings of } \\
\text { difficult words } \\
\text { - learn how to write a } \\
\text { business email } \\
\text { - discuss some } \\
\text { vocabulary or key } \\
\text { words in a text. }\end{array}$ \\
\hline
\end{tabular}

Session 12:

\begin{tabular}{|c|c|c|c|c|}
\hline $\begin{array}{c}\text { Time } \\
\text { allotment }\end{array}$ & Topic/content & $\begin{array}{l}\text { Learning } \\
\text { outcomes }\end{array}$ & $\begin{array}{l}\text { Language } \\
\text { components }\end{array}$ & Class activities \\
\hline 2 hours & $\begin{array}{l}\text { Reading a } \\
\text { manual book/ a } \\
\text { catalogue/ a } \\
\text { brochure (part I) }\end{array}$ & $\begin{array}{l}\text { Vocabulary: } \\
\text { Participants are } \\
\text { able to : } \\
\text { - recognize } \\
\text { words as } \\
\text { many as } \\
\text { possible } \\
\text { which are } \\
\text { available in a } \\
\text { catalog or a }\end{array}$ & $\begin{array}{l}\text { - vocabulary } \\
\text { used in } \\
\text { catalogues, } \\
\text { manual } \\
\text { books or } \\
\text { brochures }\end{array}$ & $\begin{array}{l}\text { - Teacher gives some } \\
\text { texts that are taken } \\
\text { from manual books and } \\
\text { catalogs. } \\
\text { - Teacher asks } \\
\text { participants to read and } \\
\text { explain what was the } \\
\text { topic about and } \\
\text { answers the questions. } \\
\text { - Teacher asks the } \\
\text { participants to search }\end{array}$ \\
\hline
\end{tabular}




\begin{tabular}{|c|c|c|c|}
\hline & 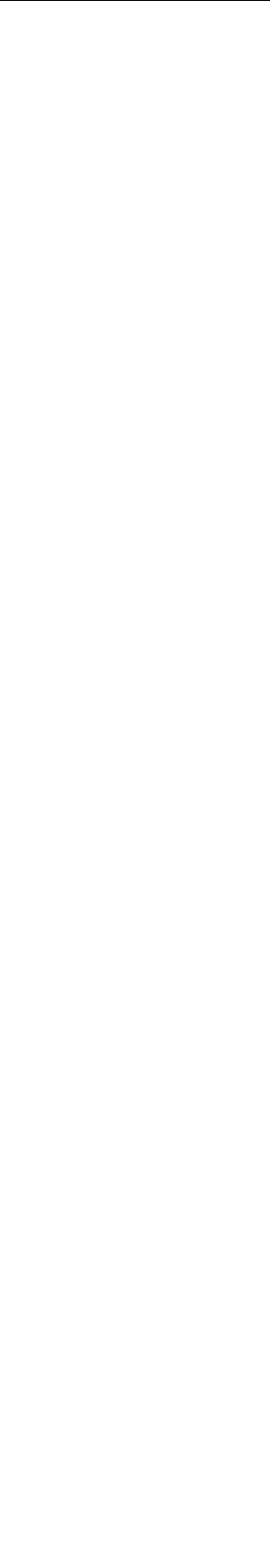 & $\begin{array}{l}\text { manual book } \\
\text { Reading : } \\
\text { Participants are } \\
\text { able to: } \\
\text { - find the } \\
\text { meanings } \\
\text { difficult } \\
\text { words } \\
\text { - capture the } \\
\text { details on a } \\
\text { text } \\
\text { - spell and } \\
\text { pronounce } \\
\text { the difficult } \\
\text { words/ } \\
\text { particular } \\
\text { words } \\
\\
\text { Speaking: } \\
\text { Participants are } \\
\text { able to: } \\
\text { retell what } \\
\text { they read }\end{array}$ & $\begin{array}{l}\text { medical equipment in } \\
\text { catalogs or brochures } \\
\text { from other companies } \\
\text { - Teacher asks the } \\
\text { participants to find } \\
\text { what information is } \\
\text { included in a catalog } \\
\text { or brochure by } \\
\text { skimming or scanning } \\
\text { - Teacher gives some } \\
\text { games } \\
\text { Participants are able to: } \\
\text { - browse a catalog or a } \\
\text { brochure of another } \\
\text { company } \\
\text { - explain and anwer the } \\
\text { questions related to the } \\
\text { brochure } \\
\text { - find the meanings of } \\
\text { difficult words and } \\
\text { practice to pronounce } \\
\text { particular words } \\
\text { - discuss some } \\
\text { vocabulary or key } \\
\text { words in the text. } \\
\text { - compare what they } \\
\text { have at their company } \\
\text { with the things they can } \\
\text { find in other } \\
\text { companies } \\
\text { - discuss with other } \\
\text { participants about their } \\
\text { findings }\end{array}$ \\
\hline
\end{tabular}

Session 13:

\begin{tabular}{|l|l|l|l|l|}
\hline $\begin{array}{c}\text { Time } \\
\text { allotment }\end{array}$ & Topic/content & \multicolumn{1}{|c|}{$\begin{array}{c}\text { Learning } \\
\text { outcomes }\end{array}$} & $\begin{array}{c}\text { Language } \\
\text { components }\end{array}$ & \multicolumn{1}{c|}{ Class activities } \\
\hline 2 hours & $\begin{array}{l}\text { Reading manual } \\
\text { book/ catalogue/ } \\
\text { brochure (part }\end{array}$ & $\begin{array}{l}\text { Vocabulary: } \\
\text { Participants are } \\
\text { able to : }\end{array}$ & $\begin{array}{l}\text { Reading } \\
\text { instructions }\end{array}$ & $\begin{array}{l}\text { - Teacher plays an online } \\
\text { dictionary and asks } \\
\text { participants to listen to } \\
\text { certain vocabulary } \\
\text { carefully. Then she or } \\
\text { he asks certain them to } \\
\text { practice pronouncing }\end{array}$ \\
& & $\begin{array}{l}\text { find the } \\
\text { meaning of }\end{array}$ & & \\
\end{tabular}




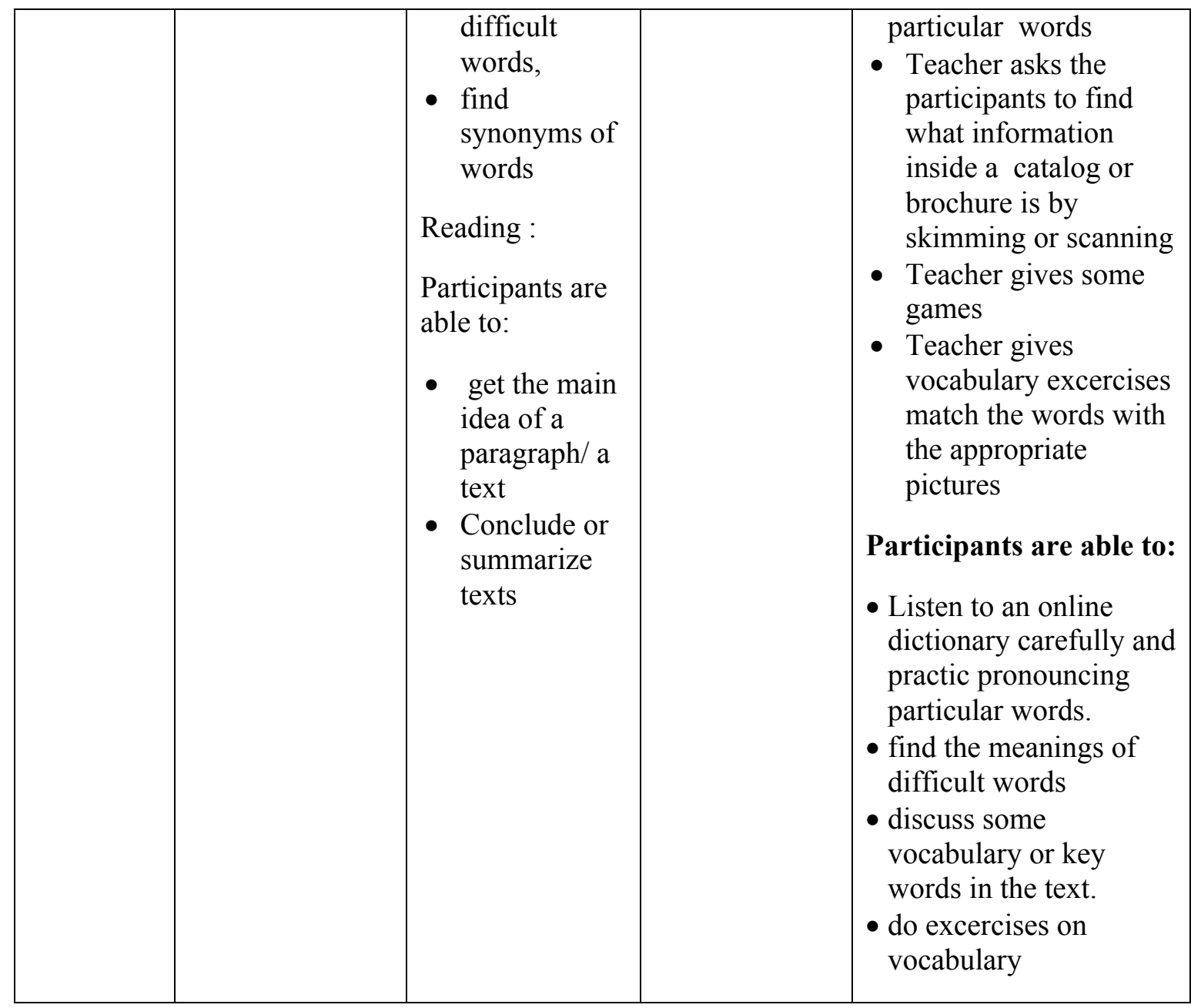

Session 14:

\begin{tabular}{|c|c|c|c|c|}
\hline $\begin{array}{c}\text { Time } \\
\text { allotment }\end{array}$ & Topic/content & $\begin{array}{l}\text { Learning } \\
\text { outcomes }\end{array}$ & $\begin{array}{l}\text { Language } \\
\text { components }\end{array}$ & Class activities \\
\hline 2 hours & $\begin{array}{l}\text { Listening to a } \\
\text { presentation } \\
\text { (about a } \\
\text { marketing staff } \\
\text { who is } \\
\text { explaining new } \\
\text { products) }\end{array}$ & $\begin{array}{l}\text { Structure: } \\
\text { Participants are } \\
\text { able to: } \\
\text { - Identify the } \\
\text { structures of } \\
\text { sentences } \\
\text { used in the } \\
\text { presentation } \\
\text { Vocabulary: } \\
\text { Participants are } \\
\text { able to } \\
\text { memorize the }\end{array}$ & $\begin{array}{l}\text { - Structure of } \\
\text { subject }+ \\
\text { Verb }+ \\
\text { Object } \\
\text { - Complex } \\
\text { sentences }\end{array}$ & $\begin{array}{l}\text { - Teacher plays a } \\
\text { cassette and asks } \\
\text { participants to listen to } \\
\text { a presentation carefully } \\
\text { - Teacher asks } \\
\text { participants what the } \\
\text { presentation is about } \\
\text { - Teacher explains the } \\
\text { structure of subject }+ \\
\text { verb + object and } \\
\text { - complex sentences } \\
\text { - Teacher asks } \\
\text { participants to do a } \\
\text { role play, performing } \\
\text { as a marketing staff }\end{array}$ \\
\hline
\end{tabular}




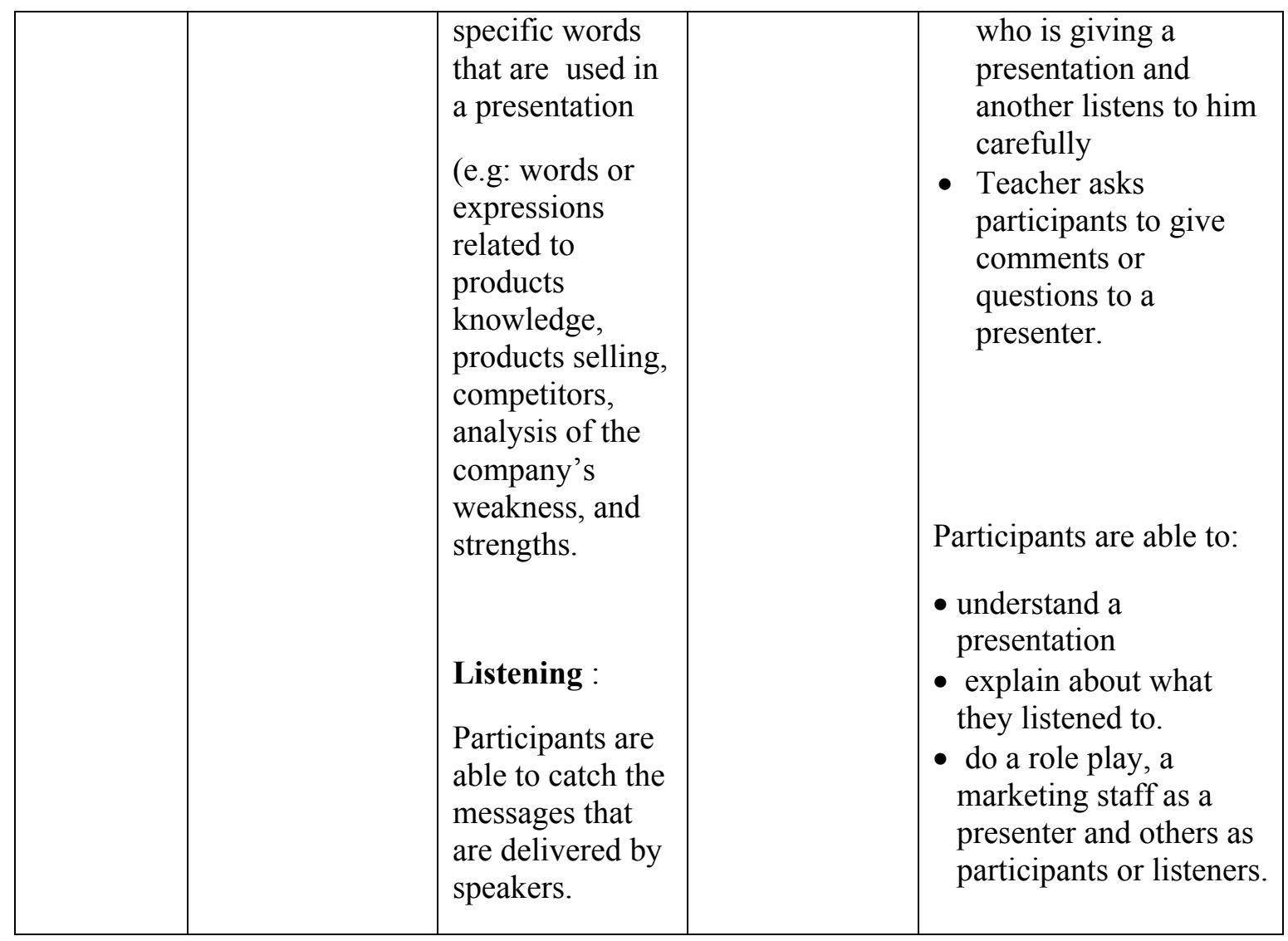

Session 15:

\begin{tabular}{|c|c|c|c|c|}
\hline $\begin{array}{c}\text { Time } \\
\text { allotment }\end{array}$ & Topic / content & $\begin{array}{l}\text { Learning } \\
\text { outcomes }\end{array}$ & $\begin{array}{c}\text { Language } \\
\text { components }\end{array}$ & Class activities \\
\hline 2 hours & $\begin{array}{l}\text { Proposing an } \\
\text { idea in a } \\
\text { meeting \& } \\
\text { presenting an } \\
\text { argument in a } \\
\text { meeting }\end{array}$ & $\begin{array}{l}\text { Structures: } \\
\text { Partipants are } \\
\text { able to : } \\
\text { - give an } \\
\text { opinion and } \\
\text { present an } \\
\text { argument } \\
\text { Vocabulary: } \\
\text { Partipants are } \\
\text { able to : } \\
\text { - memorize and } \\
\text { master words } \\
\text { related to } \\
\text { giving } \\
\text { opinions and } \\
\text { presenting } \\
\text { arguments. }\end{array}$ & $\begin{array}{l}\text { - Proposing } \\
\text { ideas in a } \\
\text { meeting } \\
\text { - Giving } \\
\text { opinions for } \\
\text { example: in } \\
\text { my opinion, } \\
\text { based on the } \\
\text { fact .... } \\
\text { - Accepting } \\
\text { and refusing } \\
\text { ideas or } \\
\text { opinions } \\
\text { politely }\end{array}$ & 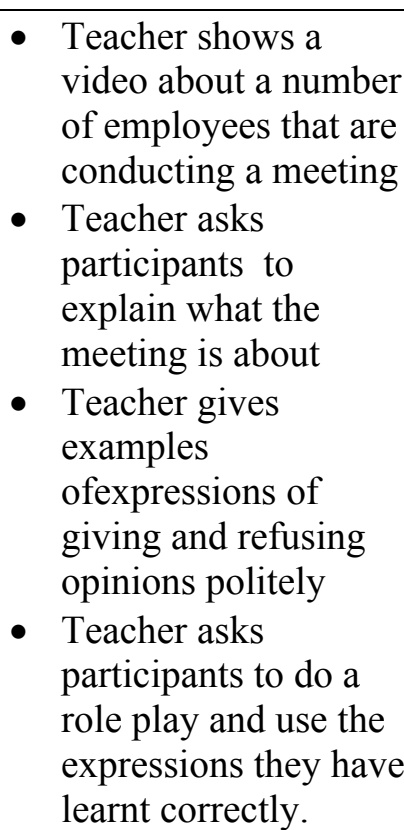 \\
\hline
\end{tabular}




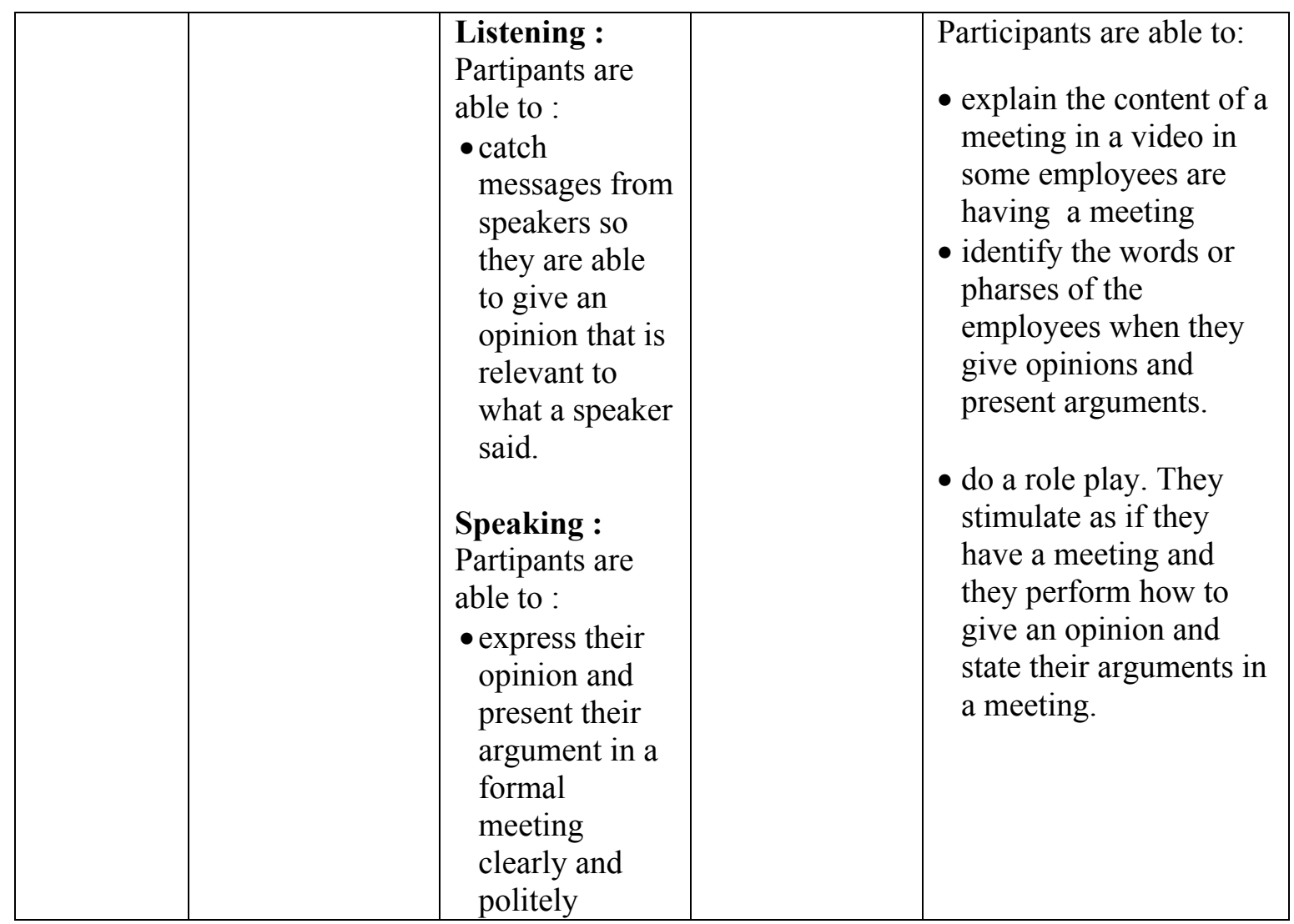

\section{CONCLUSION AND SUGGESTIONS}

\section{Conclucion}

After analyzing the collected data, the writer comes to some conclusions of the study. Firstly, according the collected data, all marketing staffs at PT. Dharma Medipro need to learn English to improve their English competencies because their routine jobs are mostly related to foreign customers and the product catalogues are written in English. The contents in the syllabus are based on the participants' needs, so it will become a fruitful syllabus. Thus, the marketing staff will attend the course enthusiasticly. Hopefully, the course will achieve the targets of the participants.

Secondly, most of the marketing staff have been working more than six years; therefore, it can be assumed that they are quite proficient in English. In fact, some of them say that they dare to speak English evethough the grammar is not good. This means that some of them kept talking in English eventhough they were not sure about the correct grammar. Because of this, teaching grammar is included in the course. Since their pronounciation also needs some improvement, pronounciation practices are also integrated in speaking and listening sessions. They also need to improve their reading skill, so that they will be able to understand the vocabulary in texts, and to comprehend the texts. Although most of the marketing staff have no difficulties in writing, they need to write when they have to give information about new products and when they have to reply to emails from customers or suppliers. Therefore, one session is allocated to improve their writing.

Thirdly, the contents of the syllabus focuses more on speaking, listening, and reading skills. The activities such as performing a role-play, watching video, drilling pronounciation, are used to develop the participants' competencies. 


\section{Suggestion}

Almost all of the marketing staff are able to speak English, and a few of them are at moderate level. The writer suggests to the teacher who will use this syllabus to learn about healthcare equipment before delivering the course. Meanwhile participants are suggested to download English online dictionary on their smart mobile phones. It is very useful to practice English pronounciation, word spelling and also to find difficult meanings.

Learning language needs continuity. It is not possible for the participants to master English in three months with once a week meeting. As the syllabus is only a prototype syllabus to start an English class in PT. Dharma Medipro, the participants are suggested to have another English course to develop other languages skills.

Finally, the writer is aware that this study is a preliminary study of designing a syllabus for marketing staff at a healthcare manufacturing company. The writer also realizes that this study is not perfect. For that reason, suggestions and comments to improve this study are welcomed to make this study more perfect and reliable. Participation, evaluation, comments from other parties in PT. Dharma Medipro could be a valuable input in developing a syllabus.

Hopefully, this syllabus could give useful contributions, especially for the marketing staff of PT. Dharma Medipro to improve their English and this study could be beneficial and might help other researchers who are interested in the field of syllabus design. 


\section{BIBLIOGRAPHY}

Basturkmen, H. 2006. Ideas and Options in English for Specific Purposes. New Jersey: Lawrence Earlbaum Associates,Inc.

Celce-Murcia, M. 2001. Teaching English as a Second or Foreign Language. Boston: Heinle \& Heinle.

Chew, K. S. 2005. An investigation of the English language skills used by new entrants in banks in Hong Kong. English for specific purposes, an International Journal , 423435.

Corner, M. 2004. Retrieved 2014, from www.agelesslearner.com: www.agelesslearner.com/intros/andragogy.html

Crystal, D. 1997. English as a global language (First edition ed.). Cambridge: Cambridge University Press.

Douglas, D. 2000. Assessing language for specific purposes. Cambridge: Cambridge University Press.

Gay, L. R., \& Diehl, P. L. 1992. Research Methods for Bussiness and Management. New York: MacMillan Publishing Company.

Graves, K. 2002. Designing Language Course: A Guide for teachers. Boston,MA: Heinle \& Heinle.

Graves, K. 1996. Teachers as course developers. Cambridge: Cambridge University Press.

Harmer, J.2007. The Practice of English language teaching (Fourth ed.). Harlow: Pearson Longman. 
Hoekje, B. J. 2007. Medical Discourse and ESP Course for international Medical Graduates (IMGs). English for specific purposes an International Journal. , 327-343.

Jacobs, T. S. 2010. Essentials for Successful English Language Teaching. London: Continuum International Publishing Group.

Jasso-Aguilar, R. 2005. Sources, methods and triangulation in needs analysis : A critical perspectives in a case study of Waikiki Hotel maids (in M H Long ed.). Cambridge: Cambridge University Press.

Jiang, S. 2011. ESBP Course Design for Chinese International Business Personnel. The Asian ESP Journal, 729-734.

John, T. D.-E. 1998. Developments in Englisgh for specific puproses. Cambridge: Cambridge University Press.

John, T. D.-E. 1998. Developments in English for specific Purposes. Cambridge: Cambridge University Press.

Johnson, C. E. (1994). Teaching business English. Oxford: Oxford University Press.

Jordan, R. R. 1997. English for academic purposes : A Guide and resource book for teachers . Cambridge: Cambridge University Press.

kontan.co.id. 2014, September 14). Retrieved 2014, from nasional.kontan.co.id: http://nasional.kontan.co.id/news/hadapi-mea-sby-terbitkan-inpres-daya-saing

Krahnke, K. 1987. Approaches to syllabus design for foreign language teaching. Englewood cliffs, New Jersey: Regents Prentice Hall.

Kumaradivelu, B. 2003. Beyond Methods : Macrostrategies for Language Teaching. London: Yale University Press.

Kumaradivelu, B. 2009. Understanding Language Teaching : From Method to Postmethod. New York: Routledge.

L Zang, C. P. 2011. New Developments of business English from ESP in China (1 ed.).

Language Learning Advisor. 2007. Retrieved from http://www.language-learningadvisor.com/age-and-language-learning.html

Long, M. H. 2005. Methodological issues in learner needs analysis (In M H Long ed.). Cambridge: Cambridge University Press.

Longman Dictionary of Contemporary English. 2006. London: Pearson Longman.

Merriam-Webster's Advance learner's English Dictionary. 2008. Springfield: Incorporated.

Mountford, R. M.1978. English for specific purposes. London: Longman.

Nunan, D. 2001. Teaching English as a Second of Foreign Language.In M Celce-Murcia ed.. Boston: Heinle \& Heinle. 
Nunan, d. 1988. The Learner Centered Curricullum. Cambridge: Cambridge University Press.

Robinson, P. 1991. ESP Today: A Practioner's Guide. London: Prentice Hall International.

Sangadji, E. M., \& sopiah. 2010. Metodologi penelitian - Pendekatan praktis dalam penelitian (1st ed.). Yogyakarta, Indonesia: ANDI.

Saraceni, M. 2010. The relocation of English : Shifting paradigms in a global era. Houndmills: Palgrave Macmillan.

Sawir, E. 2005. Language difficulties of international student in Australia: The effects of prior learning experience. International Education Journal , 6(5), 567-580.

Stevens, P. (1988). ESP after twenty years: a re-appraisal. Singapore: SEAMEO Regional Language.

Ur, P. 2003. A course in language teaching practice and theory (Tenth ed.). Cambridge: Cambridge University Press.

Waters, T. H. 1987. English for specific Purposes a learning centered approach. Cambridge: Cambridge university Press.

Yalden, J. 1986. An interactive approach to syllabus design : the Frameworks project. Oxford: pergamon Press.

Yalden, J. 1991. Principles of course design for language teaching. Cambridge: Cambridge University Press.

Zhang, Z. 2007. Towards and Integrated Approach to Teaching Business English : A Chinese Experience. English for specific purposes, An International Journal, XXV1(4), 399-410.

http://www.merriam-webster.com/dictionary/marketing

http://www.oxforddictionaries.com/definition/english/marketing (2010,March 19)

http://www.floridatechnet.org/inservice/abe/abestudent/andravsped.pdf 